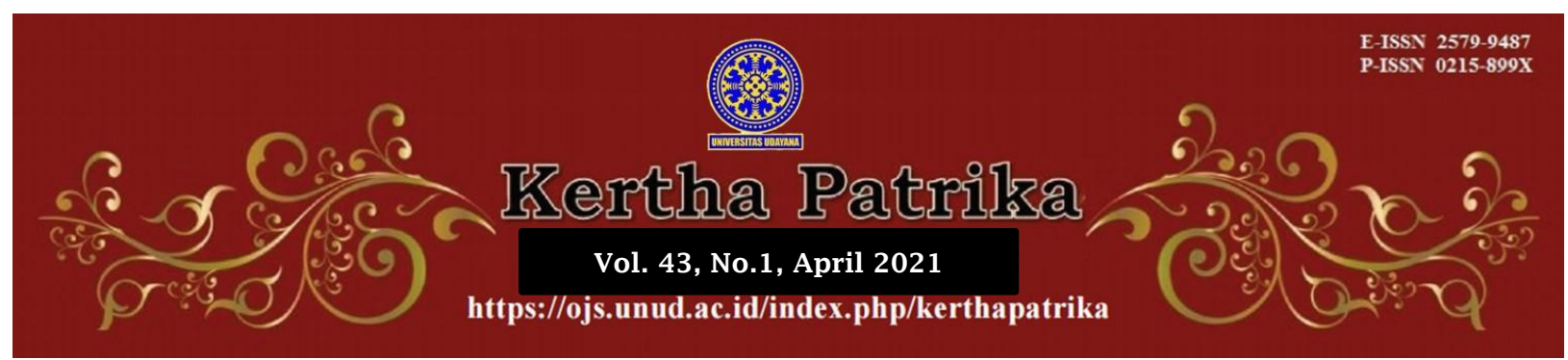

\title{
Regional Government Authority Over Collection and Auditing Regional Taxes: Indonesia Legal Perspective
}

\author{
Putu Gede Arya Sumerta Yasa1, Cokorda Dalem Dahana²
}

1Fakultas Hukum Universitas Udayana, E-mail: arya_sumerthayasa@unud.ac.id

2Fakultas Hukum Universitas Udayana, E-mail: cok dahana@unud.ac.id

\begin{tabular}{l}
\hline Info Artikel \\
Received : $23^{\text {rd }}$ February 2021 \\
Accepted : $20^{\text {th }}$ April 2021 \\
Published : $28^{\text {th }}$ April 2021 \\
Keywords : \\
Local Tax; Collection; Audit; \\
Legal Aspect \\
\\
Corresponding Author: \\
Putu Gede Arya Sumerta Yasa, \\
E-mail : \\
arya_sumerthayasa@unud.ac.id \\
DOI : \\
10.24843/KP.2021.v43.i01.p03
\end{tabular}

\begin{abstract}
Taxes as a source of State revenue are very important objects because most of the types of State revenue come from taxes. Due to this condition, it is necessary to have firm regulation for both tax authorities and taxpayers to maximize revenue from the tax sector. This writing aims to analyze the legality aspects of local government authorities in collecting and auditing local taxes. This is a normative legal research with a statutory approach and a conceptual approach. The results show that local government has the authority to collect local taxes as a consequence of the concept of regional autonomy, which emphasized that regional revenue is a source of financing for regional development. The Law of Local Taxation and Retribution provides greater authority to regions than before in administering regional taxes and levies. The enactment of the Regional Government Law and the Central and Regional Financial Balancing Law then regulates the expansion of tax objects and the determination of tax rates. Meanwhile, audit action in regional taxation is one of the efforts to save financial management by testing the correctness of the sustainability of financial planning and operations that are recorded in the form of taxpayer financial statements. This audit effort is part of the tax collection process regulated in the General Provisions and Tax Procedures in an effort to enforce central and regional tax collection.
\end{abstract}

\section{Introduction}

Taxes in general are public contributions to the State, which are based on statutory regulations and are coercive in nature, used to finance State expenditures in realizing the objectives of the State. The role of taxes for the economy of a country generally ends in two policies, namely allocation and distribution. Allocation policy refers to the importance of taxes to finance goods that are not be able to be provided by individuals (private), while distribution policies focus on taxes as a distribution scheme for the 
welfare of an individual in society. ${ }^{1}$ The tax sector has been known as a strategic source of State revenue. State revenue from tax collection requires the lowest cost compared to others, for instance by foreign loans.

Conceptually, tax is defined as the transfer of wealth from the private sector to the public (government) based on the law, which can be enforced without getting compensation or public contributions to the state treasury (transfer of wealth from the private sector to the government sector), based on the law without getting reciprocal services is used to finance general expenditures in achieving goals excluding State finances. ${ }^{2}$

According to Article 1 poin 1 of Law of the Republic of Indonesia Number 28 of 2007 concerning the Third Amendment of the Law Number 6 of 1983 on General Provision and Taxation Procedure, Tax means:"Payable mandatory contribution to the State of the individual or entity, which is coercive under the Law, without any direct return and shall be utilized for the need of the State for the greatest prosperity of the people".

Tax also has a budgetary and regulating function. ${ }^{3}$ As a budgetary function, tax is used as a source of government revenue to fund, both routine and development expenditure. Meanwhile, tax is a tool to regulate or implement government regulations and policies in the social and economic fields.

The collection of a tax depends not only on changes and differences in the regional economy but also on the administrative capacity of regional or local collections. ${ }^{4}$ Tax collection will be maximally successful if is supported by 3 things, namely: the awareness of the taxpayer, the professional ability of the tax officer (hereinafter Fiscus), and the sophistication of the tools used in tax debt collection.

Moving from the side of tax collection authority and the legal basis for the imposition of collection, taxes can be classified into central and regional/local taxes. Local taxes are taxes that fall under the authority of local governments both from the planning side to their use for the region. Local taxes are collected by the regional government with regional authority and are used for revenues in regions. The granting of autonomy to the regions in addition to paying attention to the diversity in the regions is also intended to provide space for democracy and public participation. ${ }^{5}$ Local governments are

1 Prasetyia, F. (2012). Rekonstruksi Sistem Fiskal Nasional dalam Bingkai Konstitusi. Journal of Indonesian Applied Economics, 5(2), 142 - 143.

2 Kamaroellah, R. A. (2017). Analisis Kepatuhan Wajib Pajak Bumi dan Bangunan Berdasarkan Realisasi Penerimaan Pajak Bumi dan Bangunan (PBB) pada Dinas Pendapatan Daerah Kabupaten Pamekasan. IQTISHADIA: Jurnal Ekonomi dan Perbankan Syariah, 4(1), 82-103.

3 Jamaludin, A., \& Karjoko, L. (2019). Legal Certainty of Tax Determination on acquisition Charges for Land and Building Rights (BPHTB) by Local Finance Board in Karanganyar. International Journal of Business and Social Science, 10(11), 69-75.

${ }^{4}$ Mahi, R. (2005). Peran Pendapatan Asli Daerah di Era Otonomi. Jurnal Ekonomi dan Pembangunan Indonesia, 6(1), 39-49.

${ }^{5}$ Pamuji, K. (2014). Kebijakan Pengelolaan Pajak Daerah dalam Kerangka Penyelenggaraan Otonomi Daerah (Analisa terhadap Implementasi Wewenang Pengelolaan Pajak Daerah oleh Pemerintah Pusat dan Pemerintah Daerah). Jurnal Dinamika Hukum, 14(3), 430-444. 
required to be able to identify potential sectors for regional development, especially through efforts to develop the potential for Regional Original Revenue. ${ }^{6}$

Some of the useful potential to support the development and become the needs of local governments includes: natural resource, human resource, artificial resource, and institutional resource, ${ }^{7}$ i.e. material and political. Both of these aspects in essence want an increase in tax revenue, which should minimize the additional burden (excess burden) caused by the tax system. ${ }^{8}$ Source of tax in Indonesia can be divided into National Taxation and Local Taxation. The national tax is collected from income tax $(P P h)$, valueadded tax $(P P N)$, sales tax on luxury goods $(P P n B M)$, land and building tax for the plantation sector, forestry and mining $(P P B-P 3)$, and stamp duty. While the local taxation consists of provincial taxes and regency/municipality taxes. The provincial taxes consist of Motor vehicle tax; Excise/tax for transfer of ownership of motor vehicle, motor vehicle fuel tax, surface water tax, and cigarette tax. While, the regency/municipality taxes consist of hotel tax, restaurant tax, entertainment tax, street lighting tax, tax on non-metal mineral and rock, parking tax, ground meter tax, tax on swallow' nests, rural and urban land and building tax, and excise/tax for acquiring right on land and building.

The General Taxation Provisions become the basis for every tax collection in Indonesia. There is a possibility that in determining the tax payable there is a mismatch in the amount of the tax debt, either as a result of the taxpayer's negligence in reporting the tax payable calculation of a fiscal error in determining the tax debt for the taxpayer. In order to resolve the dispute, both the taxpayer and the fiscus are obliged to comply in the applicable provisions, namely Law concerning the General Provision and Taxation Procedure. The law began with the issuance of Law Number 6 of 1983 further enchanced by Law Number 9 of 1994, Law Number 16 of 2000, most recently Law Number 28 of 2007 concerning General Provision and Taxation Procedure (hereinafter the Law of General Provision and Taxation Procedure).

In terms of concept, local taxes are state taxes that are submitted to the regions and declared as regional taxes by law. If we compare the concept above with the provisions of Law Number 28 of 2009 concerning Local Taxation and Retribution (hereinafter Law of Local Taxation), Article 1 point 10 it is stipulated, that:

"Local Tax (hereinafter Tax) shall mean obligatory contribution to the Region owed by private individuals or entities of enforced nature based on the Law, without receiving direct compensation and used for the needs of the Region mostly for the welfare of the people."

Local tax is one of the most important incomes for the region, so it is necessary to make arrangements to get maximum results by complying with applicable regulation. ${ }^{9}$ Regional governments are given the authority to make policies in order to strengthen

${ }^{6}$ Arief, A., \& Djanggih, H. (2020). Implementasi Penarikan Retribusi Izin Mendirikan Bangunan Terhadap Realisasi Pendapatan Asli Daerah. Kertha Patrika, 42(1), 73-86.

7 Anggoro, D. D. (2017). Pajak Daerah dan Retribusi Daerah. Universitas Brawijaya Press.

${ }^{8}$ Johan, A., Hikmah, F., \& Anditya, A. (2019). Perpajakan Optimal dalam Perspektif Hukum Pajak Berfalsafah Pancasila. Jurnal Magister Hukum Udayana (Udayana Master Law Journal), 8(3), 317337.

${ }^{9}$ Handayani, S. (2017). Potensi Retribusi Pasar terhadap Peningkatan Pendapatan Asli Daerah (PAD) Kabupaten Lamongan. Jurnal Penelitian Ekonomi dan Akuntansi (JPENSI), 2(1), 24Halaman. 
the regional economy in financing the development and implementation of regional governments by increasing revenues derived from Regional Original Revenue. 10 This authority is expected to not be detrimental and cause polemics that can hinder the development and progress of a region, such as a high-cost economy and hampering population mobility, traffic of goods and services between regions in regional economic activities. ${ }^{11}$ One of the efforts to increase local tax revenue can be done by developing a regional economy based on local strength for the development of regional superior commodities. ${ }^{12}$

Prior to the enactment of the Law of Local Government, around 8.000 local regulations or taxes and levies were drafted and more than 3.000 of these regulations indicate problems. The regional regulations regulating taxes and levies or various other levies were canceled because they generally contradict higher laws and regulations and are deemed to have created high economic costs and hindered the investment climate. ${ }^{13}$ This condition shows that there are still essential obstacles that must be overcome immediately in maximizing the concept of autonomy for regional development.

Apart from being related to tax collection, the audit-related aspect is also an important element related to local taxes. The provisions of Article 1 point 25 of the Law of General Provision and Taxation Procedure, which simply put as series of activities in collecting and utilizing data in terms of fulfillment of taxation. Audit are very important in the tax collection process as regulated in the General Provisions and Tax Procedures in an effort to enforce central and regional tax collection. On the basis of the aforementioned conditions, it is interesting to conduct legal research that specifically examines the legality aspects both in collecting and auditing local taxes.

Based on the statements above, it is interesting to conduct a legal research titled "Regional Government Authority Over Collection and Auditing Regional Taxes: Indonesia Legal Perspective". This research has a novelty with previous studies, which mostly dissect the tax collection with a case study approach conducted in various regions of Indonesia. This research specifically seeks to dissect and analyze in depth related to the authority of local governments in the field of taxation in Indonesia, both from the legality aspect of local tax collection and the aspect of a regional tax audit.

\section{Research Method}

This is a normative legal research with a statutory approach, the conceptual approach, and the analytical approach. The technique of collecting legal material uses literature study techniques. All data collected was then analyzed by using qualitative methods and the results were presented descriptively. According to Peter Mahmud Marzuki,

10 Hariandja, F. (2020). Pajak Daerah dan Restribusi Daerah (PDRD) Dikaitkan dengan Pertumbuhan Investasi. Jurnal Suara Hukum, 2(2), 154-183..

11 Tobing, A. J. L. (2019). Hak Uji Materiil Peraturan Daerah Pajak dan Retribusi Daerah. Jurnal Hukum \& Pembangunan, 49(2), 224-240.

12 Tahwin, M. (2013). Identifikasi Faktor-faktor yang Mempengaruhi Penerimaan Pajak Daerah. Buletin Studi Ekonomi.

${ }^{13}$ Barlian, A. E. A. (2016). Konsistensi Pembentukan Peraturan Daerah Berdasarkan Hierarki Perundang-undangan dalam Prespektif Politik Hukum. FIAT JUSTISIA: Jurnal Ilmu Hukum, 10(4), 605-622. 
normative legal research is a process that aims to find legal rules, legal principles, and legal doctrine in an effort to answer current legal problems. ${ }^{14}$

\section{Discussion and Analysis}

\subsection{The Authority of Local Government in Collecting Local Taxes}

Local taxes are one of the important incomes for the regions, so it is necessary to make arrangements to get results as targeted. The implementation of regional autonomy as a part of the regional government is defined as an effort to increase regional income in order to fulfill regional needs and development through relations in regional regulations. 15 The concept of regional autonomy has inspired regions to explore potential financial resources that exist in their regions.

The principle of regional autonomy uses the principle of the broadest possible autonomy, the principle of real autonomy and the principle of responsible autonomy. Thus, the autonomy authority given to the regions is broad, real and responsible autonomy. ${ }^{16}$ The management of revenue sources managed with the principle of autonomy are very important for carrying out the activities of each level of government, because sufficient revenue ensures the execution of government programs optimally. ${ }^{17}$

Regional autonomy as an effort to accelerate the welfare of the people is still unable to meet expectations and legal innovation or breakthroughs are needed. ${ }^{18}$ Government authority based on legal authority (legislation) is the main basis for every action or legal action at every level of government including regional government. ${ }^{19}$ However, the excessive and uncontrolled creativity of the Regional Government in collecting local taxes and levies will have an adverse impact on society and the business community, which in turn causes a high cost economy.

According to Article 18 paragraph (5) The 1945 Constitution of the Republic of Indonesia (hereinafter Indonesian Constitution) stated that: "The regional authorities shall exercise wide-ranging autonomy, except in matters specified by law to be the affairs of the central government".

Regional government affairs include matters related to the authority to make regional policies to provide services to increase community participation and empowerment aimed at improving community welfare. In carrying out its regional affairs, each region has a relationship with the government and with other local governments; which stated on provisions Article 18 paragraph (1) Indonesian Constitution.

${ }^{14}$ Fajar, M \& Achmad, Y. (2013). Dualisme Penelitian Hukum Normatif \& Empiris, Yogyakarta: Pustaka Pelajar, h. 90.

15 Setyawan, D. (2012). The Impact of Indirect Taxation on the Plantation Sector in Indonesia. Journal of Social and Development Sciences, 3(4), 135-141.

${ }^{16}$ Wulandari, P. A., \& Iryanie, E. (2018). Pajak Daerah dalam Pendapatan Asli Daerah. Deepublish.

17 Ismail, T. (2011). Implentasi Pajak Daerah dan Retribusi Daerah di Era Otonomi Daerah. Masalah-Masalah Hukum, 40(2), 256-262.

${ }^{18}$ Subadi, S., \& Toersina, T. O. (2018). Perkembangan Konsep atau Pemikiran Teoritik Tentang Diskresi Berbasis Investasi di Daerah. Mimbar Hukum-Fakultas Hukum Universitas Gadjah Mada, 30(1), 17-31.

${ }^{19}$ Muin, F. (2014). Otonomi Daerah dalam Perspektif Pembagian Urusan Pemerintah-Pemerintah Daerah dan Keuangan Daerah. Fiat Justisia, 8(1), 69-79. 
According to Law Number 23 of 2014 concerning Local Government (hereinafter Law of Local Government) provides limitations on the criteria for local taxes and levies that can be collected by the local government. ${ }^{20}$ The enactment of the Regional Government Law and Law Number 33 of 2004 concerning Central and Regional Financial Balancing are two legal instruments, which then regulate the expansion of tax objects and the determination of tax rates.

Hence, all the regional government affairs include matters related to the authority to make regional policies to provide services to increase community participation and empowerment aimed at improving community welfare. In carrying out its regional affairs, each region has a relationship with the government as well as with other local governments.

Therefore, the autonomy referred to in the administration of a state is autonomy within the corridors of the unitary state of the Republic of Indonesia. The State recognizes the existence of each region as well as maps out the rights owned by local communities who have certain territorial boundaries and are authorized to manage their own affairs based on the aspirations of the community. To support the implementation or regional autonomy, it is necessary for the Regional Government to pay attention to the opportunities that exist. Steps in the form of innovation but still referring to the laws and regulations are good to do in addition to insenifying the implementation of local tax collection and local levies that have been implemented previously. ${ }^{21}$

The guarantee of recognition of the existence of regions in the Indonesia Constitution protects regions when the regions exercise their autonomy, especially in the fair use of natural and other resources, as stipulated in Article 18A paragraph (2) of Indonesian Constitution.

Changes to decentralization and the relationship between the center and the regions have given the regions greater authority to carry out regional government tasks, which must be accompanied by the provision of funds. The authority to carry out regional autonomy is mentioned in Article 21 point e of Law Number 32 of 2004 concerning Regional Administration. Further, Article 12 paragraph (2) Law of Local Government regulates that the mandatory Government affairs are not related to the Basic Services, shall include organizing the environment.

Hence, it can be stated that the regional government has the authority to collect regional taxes as a consequence of regional autonomy, namely to receive regional revenue as the cost of development in the regions. Local taxes are taxes that are regulated by the regional government, which are carried out by levying local people. The term regional tax was integrated with regional retribution, which was originally regulated by Law Number 18 of 1987, then refined to Law 34 of 2000 and finally replaced by Law Number 28 of 2009.

${ }^{20}$ Sidik, M. (2002). Optimalisasi Pajak Daerah dan Retribusi Daerah dalam Rangka Meningkatkan Kemampuan Keuangan Daerah. Makalah disampaikan Acara Orasi Ilmiah. Bandung, 10.

${ }^{21}$ Riduansyah, M. (2010). Kontribusi Pajak Daerah dan Retribusi Daerah Terhadap Pendapatan Asli Daerah (PAD) dan Anggaran Pendapatan dan Belanja Daerah (APBD) Guna Mendukung Pelaksanaan Otonomi Daerah (Studi Kasus Pemerintah Daerah Kota Bogor). Hubs-Asia, 10(1). 
With the issuance of Law on Taxes and Retributions, each region are given greater authority than before in terms of management of regional taxes and levies in line with the enactment of Law Number 32 of 2004 and the Central and Regional Financial Balance Law, especially in expanding the tax base or object and determining tax rates. Although the regions are given an expansion of authority in regulating regional taxes and levies, such as regulating land and building taxes, fees for acquisition of rights on land and/or buildings, Swallow's Nest Tax and Cigarette Tax, the regions still pay attention not to the taxes and levies that cause high-cost economies and/or inhibits population mobility, traffic of goods and services between regions and disrupts export-import activities. According to Article 2 of Law of Local Taxation it is clearly mentioned the types of provincial Taxes and regency/municipality taxes, hereby: provincial taxes and regency/ municipality taxes.

The granting of wider authority to regions to regulate regional taxes and levies is in the context of strengthening regional financial revenues. Taxes that can only be collected by the State are one of the government's interferences in the economic sector to provide social protection, because people need social protection from the risks of poverty, health, and the risk of unemployment in the long run. Prior to the enactment of the Law of Local Government, around 8.000 local regulations or taxes and levies were drafted and more than 3.000 of these regulations indicate problems. The regional regulations regulating taxes and levies or various other levies were canceled because they generally contradict higher laws and regulations and are deemed to have created high economic costs and hindered the investment climate. ${ }^{22}$ This condition shows that there are still essential obstacles that must be overcome immediately in maximizing the concept of autonomy for regional development.

The debate over the central government or regional government can provide social security is a basis for thinking according to Gramlich "It is the central government that is more efficient in organizing it because in fact people are gathered centrally due to urbanization or mobility of people between regions". ${ }^{23}$ Whereas, according to Buchanan stated that: "revenue redistribution can be carried out effectively if it is carried out by local governments, because local governments know the needs and types of local public goods". ${ }^{24}$ From a practical point of view, the role of regional government in Indonesia can be considered very dominant since the era of regional autonomy; therefore the regions themselves must be able to be more independent in carrying out development in their regions. Based on the tax function as a (financial) budgeter, efforts are needed to increase tax revenue. One of the ways that the local tax collection can be achieved according to the target is to carry out an orderly tax administration for taxpayers and tax officials, especially for types of taxes that end.

In order to support the goals of both central government or regional government, it is important to emphasize the obligation of the taxpayer, for instance in making

22 Barlian, A. E. A. Loc. cit.

${ }^{23}$ Oktavia, D. (2014). Flypaper Effect: Fenomena Serial Waktu dan Lintas Kabupaten Kota Di Jawa Timur 2003-2013. Jurnal Akuntansi Universitas Jember, 12(2).

${ }^{24}$ Nadeak, I. J. (2008). Analisis Pengelolaan Dana Bantuan Langsung Tunai (BLT) dalam Pencapaian Efektivitas Dana Program Kompensasi Pengurangan Subsidi Bahan Bakar Minyak (PKPS-BBM) di Kecamatan Rantau Selatan Kabupaten Labuhanbatu. Jurnal Ilmu Administrasi: Media Pengembangan Ilmu dan Praktek Administrasi, 5(2), 01. 
bookkeeping as stated in Article 28 of the Law of General Provision and Taxation Procedure. In every business unit, whether in the form of an individual or a business entity, there will always be records about the flow or entry and exit of goods or services, which can eventually be converted into a detailed, structure, and detailed business record is often referred to as business bookkeeping. ${ }^{25}$ Bookkeeping can simply describe as process of recording and collecting data and financial information, including all the assets, liabilities, income and expenses.

The obligation to keep bookkeeping is more aimed at taxpayers related to the Income Tax Law and the Value Added Tax Law. The use of bookkeeping and recording is a guide for taxpayers to determine the amount of tax owed or used as a basis for imposing payable taxes, and can also function as documentary evidence in the event of a tax dispute, both outside and within the Tax Court. ${ }^{26}$ Bookkeeping is required to refer to several requirements determined by laws and regulations in order to have a common standard. The requirements are: based on good faith, and reflecting actual business conditions, held in Indonesia using Latin letters, Arabic numerals and rupiah(IDR) currency units, compiled in Indonesian or in a foreign language as permitted by the Minister of Finance. Accrual system is a method of determining the calculation of income and expenses in the sense that income is recognized when it is earned and expenses are recognized when it becomes payable. Thus, it does not use profit and cost calculations at concrete times (cash). Cash system is a method of calculation based on the income received and expenses paid in cash.

The function of bookkeeping or business activity recording is very useful in determining the basic calculation for the imposition of tax payable on taxpayer by taxpayers and for examining tax payable by tax officers. In Regional Taxes and Retribution, the obligation to make books or records is regulated in Article 169 paragraph (1) that "Taxpayers who conduct business with a turnover of at least $R p 300.000 .000$ (three hundred million rupiah) per year are required to maintain books or records, and the procedures are regulated by Regional Regulation".

\subsection{The Authority of Local Government in Auditing Local Taxes}

The granting of authority to regions to collect taxes is a political reality so that what is needed by the Regional Government is an increase in Regional Original Revenue, such as the implementation of tax audits. ${ }^{27}$ For Regional Original Revenue of Regional Governments that still rely on the regional tax sector, local governments should intensify taxpayers, namely updating existing taxpayer data, and extensification, namely expanding the revenue base for new taxpayers or optimally exploring other sources of revenue legitimate, which has the potential to increase the Regional Original Revenue. It is important to carry out intensive supervision of the collection of local taxes, to

25 Rori, H. (2013). Analisis Penerapan Tax Planning Atas Pajak Penghasilan Badan. Jurnal EMBA: Jurnal Riset Ekonomi, Manajemen, Bisnis dan Akuntansi, 1(3).

${ }^{26}$ Budiandru, B. (2017). Penerapan Perencanaan Pajak PPH 21 Sebagai Upaya Mengefisiensikan Pajak Penghasilan Pada PT B Net Indonesia. Jurnal Manajemen Indonesia, 17(3), 219-226.

27 Ardiansyah, B. G., \& Utomo, R. (2018). Penguatan Kapasitas Pemerintah Daerah dengan Pemeriksaan Pajak. Prosiding Sembadha, 1(1), 125-129.. 
provide legal sanctions for tax officers who abuse their authority, and to reward fiscus who excel. ${ }^{28}$

In fulfilling the tax revenue target, the tax officer is obliged to carry out activities to ascertain the obstacle that causes the decrease or not the achievement of the tax target in the sense that the number of tax recipients is not supported by the number of taxpayers, the actions of the tax officer, in this case, are known as tax audits. Tax audit is a means to supervise and foster taxpayers, apart from of course aimed at testing the level of taxpayer compliance in meeting tax obligations. ${ }^{29}$ The audit is a guard fence so that taxpayers remain in the corridor of tax and tax regulations in carrying out their duties not only for formal activities, but also to strengthen the truth of transaction and legal compliance with applicable laws. ${ }^{30}$

According to Article 29 of the Law of General Provision and Taxation Procedure, it stipulated that:

(1) Director General of Tax shall be authorized to conduct an audit to access to compliance of the fulfillment of taxation liability of the Taxpayer and for the other purpose in the contect of implementing the provision of taxation legislation;

(2) For the purpose of audit, the auditor should possess the identity as the auditor and shall be completed with the Warrant of Examination as well showing to the Taxpayer to be audited.

The purpose of the audit is to test compliance with the fulfillment of tax obligations by:

1. A notification letter showing the overpayment of tax and/or compensation;

2. Notification letter that is not delivered or not delivered on time;

3. Data and/or information in the notification letter deviates from the fairness;

4. There are indications of other tax obligations.

The authority to inspect local taxpayers is carried out by the regional government as stipulated in Article 170 paragraph (1) of the Law of General Provision and Taxation Procedure: "The regional head has the authority to conduct audits to test compliance with the fulfillment of regional tax obligations and retribution obligations in the context of implementing statutory regulation about regional tax and retribution".

An examination that tests the fulfillment of tax obligations must be carried out by tracing the correctness of notification letters, books, or records and the fulfillment of other tax obligations. In this regards, there are two ways can be done:

1. Apply examination technique commonly used in examinations in general (complete examination); or

2. Implement inspection techniques with simple weights and depths in accordance with the examination room both in the office and in the field (simple).

${ }^{28}$ Marita, N. M., \& Suardana, K. A. (2016). Pengaruh Pajak Daerah Pada Pendapatan Asli Daerah di Kota Denpasar. E-Jurnal Akuntansi, 14(1), 53-65..

29 Bwoga, H. (2005). Pemeriksaan pajak di Indonesia. Grasindo.

${ }^{30}$ Dewi, I. G. A. C. S., \& Supadmi, N. L. (2014). Pengaruh Pemeriksaan Pajak, Kesadaran, Kualitas Pelayanan Pada Tingkat Kepatuhan Wajib Pajak Badan. E-Jurnal Akuntansi, 9(2), 505-514 
Meanwhile, the other purposes for tax audits can also be used to grant a position of NPWP, gathering materials for the preparation of the Net income calculation, as well as determination of taxpayer. Hence, the examination of the taxpayers is carried out by the Director General of Taxes. The Director General of Taxes conducts an examination of the types of central taxes, while the examination of regional taxes and levies is carried out based on the authority of the regional government, which is then carried out by the Regional Revenue Service.

Whereas, the general inspection includes, the examination is carried out at the tax office of the auditing office by collecting the checked documents and field inspections at the taxpayer' business activities. In the act of inspection by the tax officer, the examinee has legal obligations:

1. To provide an opportunity for officers to enter a place or space that is a place or business to store books, notes, documents, and movable or immovable property which can provide guidance on conditions related to business income;

2. Submit data relating to business circulation in the form of cash flow, flow of goods, monthly reports, bank statements, shares and assets owned both domestically and abroad;

3. Provide other information related to third parties in their business activities.

Examination conducted by the tax officer is obliged to make a report on the results of an audit which includes: a report in a concise and clear form detailing; the scope of the purpose of the audit, the conclusion or irregularities or not, and disclosing related information and if it is related to the inspection of tax returns, the inspection documents must contain; the comparison factor, the absolute value of the deviation, the nature of the deviation, the indication or the finding that there is a deviation and the impact of the deviation and its relationship to other problems. With a gradual and comprehensive Tax Audit, it will be identified which is the Potential for Regional Tax Revenue and which is not Potential for Regional Tax Revenue, especially for the Regional Financial and Asset Management Revenue Service besides being able to identify the Potential Tax Revenue, it can also be the Financial Management Revenue Service Regional Asses determines the target of Regional tax revenue, especially for the next period. ${ }^{31}$

\section{Conclusion}

The authority of local governments in collecting regional taxes is part of the consequences of regional autonomy that encouraging regional revenue for developing the regions. The Law on Local Taxation and Retribution provides greater authority to regions than before in administering regional taxes and levies. The enactment of the Regional Government Law and the Law on Fiscal Balance between the Central dan Regional Governments has expanded tax objects and determinate tax rates. Audit action in taxation is one of the efforts to save financial management to test the correctness of the suitability of financial planning and operations recorded in the form of taxpayer financial statements. In the examination process by the fiscus of taxpayer, readiness, honesty and courage are very necessary for carrying out tasks for the sake of saving

${ }^{31}$ Kurniawan, R. (2018). Pengaruh Pemeriksaan Pajak Daerah Terhadap Penerimaan Pajak Daerah di Kota Tangerang Selatan. Fair Value: Jurnal Ilmiah Akuntansi dan Keuangan, 1(1), 2940. 
State finances. Testing of the fulfillment of tax payable can be carried out on documents, notification letters, thus honesty is created by taxpayers who can finally implement selfassessment in tax collection.

\section{Reference}

\section{Book}

Anggoro, D. D. (2017). Pajak Daerah dan Retribusi Daerah. Universitas Brawijaya Press. Bwoga, H. (2005). Pemeriksaan pajak di Indonesia. Grasindo.

Fajar, M \& Achmad, Y. (2013). Dualisme Penelitian Hukum Normatif \& Empiris, Yogyakarta: Pustaka Pelajar.

Wulandari, P. A., \& Iryanie, E. (2018). Pajak Daerah dalam Pendapatan Asli Daerah. Deepublish.

\section{Journal}

Ardiansyah, B. G., \& Utomo, R. (2018). Penguatan Kapasitas Pemerintah Daerah Dengan Pemeriksaan Pajak. Prosiding Sembadha, 1(1), 125-129.

Arief, A., \& Djanggih, H. (2020). Implementasi Penarikan Retribusi Izin Mendirikan Bangunan Terhadap Realisasi Pendapatan Asli Daerah. Kertha Patrika, 42(1), 73-86.

Barlian, A. E. A. (2016). Konsistensi Pembentukan Peraturan Daerah Berdasarkan Hierarki Perundang-undangan dalam Prespektif Politik Hukum. FIAT JUSTISIA: Jurnal Ilmu Hukum, 10(4), 605-622.

Budiandru, B. (2017). Penerapan Perencanaan Pajak PPH 21 Sebagai Upaya Mengefisiensikan Pajak Penghasilan Pada PT B Net Indonesia. Jurnal Manajemen Indonesia, 17(3), 219-226.

Dewi, I. G. A. C. S., \& Supadmi, N. L. (2014). Pengaruh Pemeriksaan Pajak, Kesadaran, Kualitas Pelayanan Pada Tingkat Kepatuhan Wajib Pajak Badan. E-Jurnal Akuntansi, 9(2), 505-514.

Handayani, S. (2017). Potensi Retribusi Pasar terhadap Peningkatan Pendapatan Asli Daerah (PAD) Kabupaten Lamongan. Jurnal Penelitian Ekonomi dan Akuntansi (JPENSI), 2(1), 24-Halaman.

Hariandja, F. (2020). Pajak Daerah dan Restribusi Daerah (PDRD) Dikaitkan dengan Pertumbuhan Investasi. Jurnal Suara Hukum, 2(2), 154-183.

Ismail, T. (2011). Implentasi Pajak Daerah dan Retribusi Daerah di Era Otonomi Daerah. Masalah-Masalah Hukum, 40(2), 256-262.

Jamaludin, A., \& Karjoko, L. (2019). Legal Certainty of Tax Determination on acquisition Charges for Land and Building Rights (BPHTB) by Local Finance Board in Karanganyar. International Journal of Business and Social Science, 10(11), 69-75.

Johan, A., Hikmah, F., \& Anditya, A. (2019). Perpajakan Optimal dalam Perspektif Hukum Pajak Berfalsafah Pancasila. Jurnal Magister Hukum Udayana (Udayana Master Law Journal), 8(3), 317-337.

Kamaroellah, R. A. (2017). Analisis Kepatuhan Wajib Pajak Bumi dan Bangunan Berdasarkan Realisasi Penerimaan Pajak Bumi dan Bangunan (PBB) pada Dinas Pendapatan Daerah Kabupaten Pamekasan. IQTISHADIA: Jurnal Ekonomi dan Perbankan Syariah, 4(1), 82-103. 
Kurniawan, R. (2018). Pengaruh Pemeriksaan Pajak Daerah Terhadap Penerimaan Pajak Daerah di Kota Tangerang Selatan. Fair Value: Jurnal Ilmiah Akuntansi dan Keuangan, 1(1), 29-40.

Mahi, R. (2005). Peran Pendapatan Asli Daerah di Era Otonomi. Jurnal Ekonomi dan Pembangunan Indonesia, 6(1), 39-49.

Marita, N. M., \& Suardana, K. A. (2016). Pengaruh Pajak Daerah Pada Pendapatan Asli Daerah di Kota Denpasar. E-Jurnal Akuntansi, 14(1), 53-65.

Muin, F. (2014). Otonomi Daerah dalam Perspektif Pembagian Urusan PemerintahPemerintah Daerah dan Keuangan Daerah. Fiat Justisia, 8(1), 69-79.

Nadeak, I. J. (2008). Analisis Pengelolaan Dana Bantuan Langsung Tunai (BLT) Dalam Pencapaian Efektivitas Dana Program Kompensasi Pengurangan Subsidi Bahan Bakar Minyak (PKPS-BBM) di Kecamatan Rantau Selatan Kabupaten Labuhanbatu. Jurnal Ilmu Administrasi: Media Pengembangan Ilmu dan Praktek Administrasi, 5(2), 01.

Oktavia, D. (2014). Flypaper Effect: Fenomena Serial Waktu dan Lintas Kabupaten Kota Di Jawa Timur 2003-2013. Jurnal Akuntansi Universitas Jember, 12(2).

Pamuji, K. (2014). Kebijakan Pengelolaan Pajak Daerah dalam Kerangka Penyelenggaraan Otonomi Daerah (Analisa terhadap Implementasi Wewenang Pengelolaan Pajak Daerah oleh Pemerintah Pusat dan Pemerintah Daerah). Jurnal Dinamika Hukum, 14(3), 430-444.

Prasetyia, Ferry. (2012). Rekonstruksi Sistem Fiskal Nasional Dalam Bingkai Konstitusi. Journal of Indonesian Applied Economics, 5(2), h. 142 - 143.

Riduansyah, M. (2010). Kontribusi pajak daerah dan retribusi daerah Terhadap pendapatan asli daerah (PAD) dan anggaran Pendapatan dan belanja daerah (APBD) guna mendukung Pelaksanaan Otonomi Daerah (Studi Kasus Pemerintah Daerah Kota Bogor). Hubs-Asia, 10(1).

Rori, H. (2013). Analisis Penerapan Tax Planning Atas Pajak Penghasilan Badan. Jurnal EMBA: Jurnal Riset Ekonomi, Manajemen, Bisnis dan Akuntansi, 1(3).

Setyawan, D. (2012). The Impact of Indirect Taxation on the Plantation Sector in Indonesia. Journal of Social and Development Sciences, 3(4), 135-141.

Sidik, M. (2002). Optimalisasi Pajak Daerah dan Retribusi Daerah dalam Rangka Meningkatkan Kemampuan Keuangan Daerah. Makalah disampaikan Acara Orasi Ilmiah. Bandung, 10.

Subadi, S., \& Toersina, T. O. (2018). Perkembangan Konsep atau Pemikiran Teoritik Tentang Diskresi Berbasis Investasi di Daerah. Mimbar Hukum-Fakultas Hukum Universitas Gadjah Mada, 30(1), 17-31.

Tahwin, M. (2013). Identifikasi Faktor-faktor yang Mempengaruhi Penerimaan Pajak Daerah. Buletin Studi Ekonomi.

Tobing, A. J. L. (2019). Hak Uji Materiil Peraturan Daerah Pajak dan Retribusi Daerah. Jurnal Hukum \& Pembangunan, 49(2), 224-240.

\section{Law and Regulation}

The 1945 Constitution of the Republic of Indonesia

Law of the Republic of Indonesia Number 32 of 2004 concerning Regional Administration, State Gazette of the Republic of Indonesia of 2004 Number 125, Supplement of the State Gazette of the Republic of Indonesia Number 4437.

Law of the Republic Of Indonesia Number 33 of 2004 concerning Fiscal Balance Between the Central Government and the Regional Governments, State Gazette of the 
Republic of Indonesia of 2004 Number 126, Supplement of the State Gazette of the Republic of Indonesia Number 4438

Law of the Republic of Indonesia Number 28 of 2007 concerning the Third Amendment of the Law Number 6 of 1983 on General Provision and Taxation Procedure, State Gazette of the Republic of Indonesia Year 2007 Number 85, Supplement of the State Gazette of the Republic of Indonesia Number 4740.

Law of the Republic of Indonesia Number 28 of 2009 concerning Local Taxation and Retribution, State Gazette of the Republic of Indonesia Year 2009 Number 130, Supplement of the State Gazette of the Republic of Indonesia Number 5049.

Law of the Republic of Indonesia Number 23 of 2014 concerning Local Government, State Gazette of the Republic of Indonesia Year 2014 Number 244, Supplement of the State Gazette of the Republic of Indonesia Number 5587 